\title{
RESEARCH
}

Open Access

\section{Intercalary prosthetic replacement is a reliable solution for metastatic humeral shaft fractures: retrospective, observational study of a single center series}

\author{
Zhiqing Zhao, Zhipeng Ye, Taiqiang Yan ${ }^{*}$, Xiaodong Tang, Wei Guo and Rongli Yang
}

\begin{abstract}
Background: Treatments for metastatic fracture of the humeral shaft continue to evolve as advances are made in both oncological and operative management. The purposes of this study were to critically evaluate the effectiveness of intercalary endoprostheses in treating metastatic humeral shaft fractures and to clarify the surgical indications for this technique.

Methods: Sixty-three patients treated surgically for 66 metastatic fractures of the humerus shaft were retrospectively reviewed. Intramedullary nailing (IMN) was performed in 16 lesions, plate fixation (PF) in 33 lesions, and prosthetic replacement in 17 lesions. The operative time, intraoperative blood loss, and postoperative complications were noted. The function of the upper extremities was assessed by the Musculoskeletal Tumor Society (MSTS) score and American Shoulder and Elbow Surgeons (ASES) score. All included patients were followed until reconstructive failure or death.

Results: The operative time was relatively shorter in the prosthesis group than in either the IMN group ( $p=0.169)$ or PF group ( $p=0.002)$. Notably, intraoperative blood loss was significantly less in the prosthesis group than in either the IMN group $(p=0.03)$ or PF group ( $p=0.012$ ). The average follow-up time was 20.3 (range, 3-75) months, and the overall survival rate was $59.7 \%$ at 12 months and $46.7 \%$ at 24 months. One rotator cuff injury, 3 cases of iatrogenic radial nerve palsy, 5 cases of local tumor progression, and 1 mechanical failure occurred in the osteosynthesis group, whereas one case of aseptic loosening of the distal stem and one case of local relapse were observed in the prosthesis group. There were no significant differences in functional scores among the three groups.

Conclusions: Intercalary prosthetic replacement of the humeral shaft may be a reliable solution for pathologic fractures patients; it is indicated for lesions with substantial bone loss, or accompanied soft tissue mass, or for those patients with better prognosis.
\end{abstract}

Keywords: Metastasis, Humeral shaft, Intramedullary nailing, Plate fixation, Intercalary prosthesis

* Correspondence: yantqzh@163.com

Musculoskeletal Tumor Center, Peking University People's Hospital, Beijing 100044, China

C The Author(s). 2021 Open Access This article is licensed under a Creative Commons Attribution 4.0 International License, which permits use, sharing, adaptation, distribution and reproduction in any medium or format, as long as you give appropriate credit to the original author(s) and the source, provide a link to the Creative Commons licence, and indicate if changes were made. The images or other third party material in this article are included in the article's Creative Commons licence, unless indicated otherwise in a credit line to the material. If material is not included in the article's Creative Commons licence and your intended use is not permitted by statutory regulation or exceeds the permitted use, you will need to obtain permission directly from the copyright holder. To view a copy of this licence, visit http://creativecommons.org/licenses/by/4.0/. The Creative Commons Public Domain Dedication waiver (http://creativecommons.org/publicdomain/zero/1.0/) applies to the data made available in this article, unless otherwise stated in a credit line to the data. 


\section{Introduction}

The humerus is the second most common long bone affected by metastatic diseases, following the femur, and the incidence of pathologic fractures has been reported to range from 16 to $27 \%$ [1-3]. Conservative treatment does not lead to significant bone healing because the tumor cells grow rapidly and overwhelm the bone's reparative process [4]. Radiotherapy alone can partially relieve pain but may further delay bone healing and the restoration of function $[5,6]$. Consequently, a growing number of studies have suggested that patients with metastatic humeral shaft fractures benefit from surgical stabilization [7-10].

Different surgical options have been described in previous studies [7, 11-15]. Intramedullary nailing (IMN) can be carried out by a closed or open procedure [12], but it may cause rotator cuff injury, whereas plate fixation (PF) requires extensive stripping of the soft tissues from the bone [16]. During the last decade, tyrosine kinase inhibitors, in particular gefitinib, sorafenib, and bortezomib, have been introduced into routine practice for first-line treatment against advanced nonsmall cell lung cancer, renal cell carcinoma, and multiple myeloma, and the survival of these metastatic patients has been considerably improved owing to these latest oncological treatments. Many cancer surgeons prefer more aggressive treatments to provide lasting palliation. This has led to the application of surgical techniques used for the treatment of primary sarcomas in bone $[17,18]$. Therefore, when possible, more radical treatment is needed for some patients with solitary bone lesions and a longer predicted life expectancy. Encouraging results regarding the application of intercalary prostheses have been obtained from studies on intercalary prostheses, leading to the expansion of surgical indications and controversy regarding the treatment of choice $[13,19,20]$. Additionally, mechanical studies conducted in vitro have indicated that prostheses provide a stronger construct than IMN does in a model of humeral segmental defects [21,22].

This study is a retrospective evaluation of a single center experience of 66 humerus shaft fractures treated by IMN, PF, and intercalary prosthetic reconstruction. The aims were to offer adequate individual treatment to the patient and try to clarify the indications for prosthetic surgical procedures. Our hypothesis was that prosthetic replacement can reduce the operative time, intraoperative blood loss, and postoperative complications more than intramedullary nailing or plate fixation.

\section{Materials and methods}

\section{Inclusion and exclusion criteria}

This retrospective study was approved by the Ethical Review Committee (ERC), and the requirement for informed consent from all subjects was waived. We retrospectively reviewed the patients between 2005 and 2018. The inclusion criteria were as follows: (i) patients with pathological fractures of the humeral diaphysis due to a metastatic disease, (ii) patients who received surgical treatment, and (iii) patients with available demographic and medical records. The exclusion criteria were (i) a fracture caused by primary malignant or benign bone tumors, (ii) involvement of the articular surface or entire humerus, and (iii) a history of revision of the initial surgery performed at an outside institution.

\section{Patient characteristics}

According to the aforementioned criteria, sixty-three patients were included. Bilateral humeral shaft fractures were observed in 3 patients, leading to a total of 66 procedures. All surgical procedures were performed by the same team of trained orthopedic oncology surgeons. Among the methods used for definitive treatment, the most prevalent was open reduction and internal fixation with plates and screws, followed by intercalary prostheses and IMN, and these methods were performed for 33 (50\%) cases, 17 cases, and 16 cases, respectively. Before 2012, only IMN and PF were used, but since 2012, intercalary prostheses have been used in select patients in an attempt to improve disease control; however, osteosynthetic techniques have continued to be used. The study population comprised 33 males and 30 females, with a mean age of $62.3 \pm 10.7$ years (range, $39-82$ years) at diagnosis (Table 1). The mean interval between the diagnosis of the primary tumor and the development of humeral shaft metastasis was $13.5 \pm 25.6$ months (range, $0-120$ months). The primary lesions were myeloma in 18 cases, lung cancer in 18, renal cancer in 11, breast cancer in 4, thyroid carcinoma in 2, and other types in 10. Metastatic lesions were located at the upper, middle, and lower $1 / 3$ of the humerus diaphysis in 11, 49, and 6 cases, respectively (Fig. 1). A total of 41 patients had multiple bone metastases. Complete pathologic fractures were seen in 40 lesions, and accompanying soft-tissue masses were observed in 29 lesions. The average Mirel's score in patients with impending fractures was 8.4, and the scores ranged from 8 to 9 . The presence of visceral metastases was found in seventeen patients $(27.0 \%, 17 / 63)$. All patients suffered from severe pain and dysfunction of the arm, which severely affected their ability to perform activities of daily living. Twenty patients $(31.7 \%, 20 / 63)$ received chemotherapy and/or radiotherapy for primary lesions before surgery. Only one patient received radiotherapy for humeral metastatic lesions. More details about the type of fracture, presentation of visceral metastases, Karnofsky performance score (KPS), visual analog scale (VAS) score, Mirel's score, and TNM stage are exhibited in Supplementary Table I. 
Table 1 Patients and treatment characteristics

\begin{tabular}{|c|c|}
\hline Variable & No. [\%] \\
\hline Operations & 66 \\
\hline Patients & 63 \\
\hline Male & $33[52]$ \\
\hline Female & $30[48]$ \\
\hline Mean age (years) & 62.3 (SD, 10.7; range, 39-82) \\
\hline \multicolumn{2}{|l|}{ Primary tumor } \\
\hline Lung cancer & 18 [29] \\
\hline Myeloma & 18 [29] \\
\hline Renal carcinoma & $11[17]$ \\
\hline Breast cancer & $4[6]$ \\
\hline Thyroid & $2[3]$ \\
\hline Others & $10[16]$ \\
\hline Karnofsky score & 68.9 (range, 30-90) \\
\hline Mirel's score & 8.4 (range, 8-9) \\
\hline \multicolumn{2}{|l|}{ Skeletal metastasis } \\
\hline Solitary & $22[35]$ \\
\hline Multiple & $41[65]$ \\
\hline \multicolumn{2}{|l|}{ Type of fracture } \\
\hline Complete & $40[61]$ \\
\hline Impending & 26 [39] \\
\hline \multicolumn{2}{|c|}{ Accompanied soft tissue mass } \\
\hline Yes & $29[44]$ \\
\hline No & $37[56]$ \\
\hline \multicolumn{2}{|l|}{ Visceral metastases } \\
\hline Yes & $17[27]$ \\
\hline No & $46[73]$ \\
\hline \multicolumn{2}{|l|}{ Surgery } \\
\hline IMN & $16[24]$ \\
\hline PF & $33[50]$ \\
\hline Prosthesis & 17 [26] \\
\hline
\end{tabular}

Perioperative events were noted regarding the operating duration $(\mathrm{min})$, intraoperative blood loss $(\mathrm{ml})$ and postoperative complications. At the final follow-up, a postoperative functional assessment was carried out using the American Shoulder and Elbow Surgeons (ASES) [23] and Musculoskeletal Tumor Society (MSTS) scales [24]. All included patients were followed until reconstructive failure or death.

\section{Surgical options}

Closed reduction and stabilization with anterograde unreamed locked nail insertion were performed in patients with bilateral humeral shaft fractures, and poor survival was estimated. Open IMN or plates are acceptable when adequate proximal and distal cortical bone is present for screw purchase. Additionally, preoperative

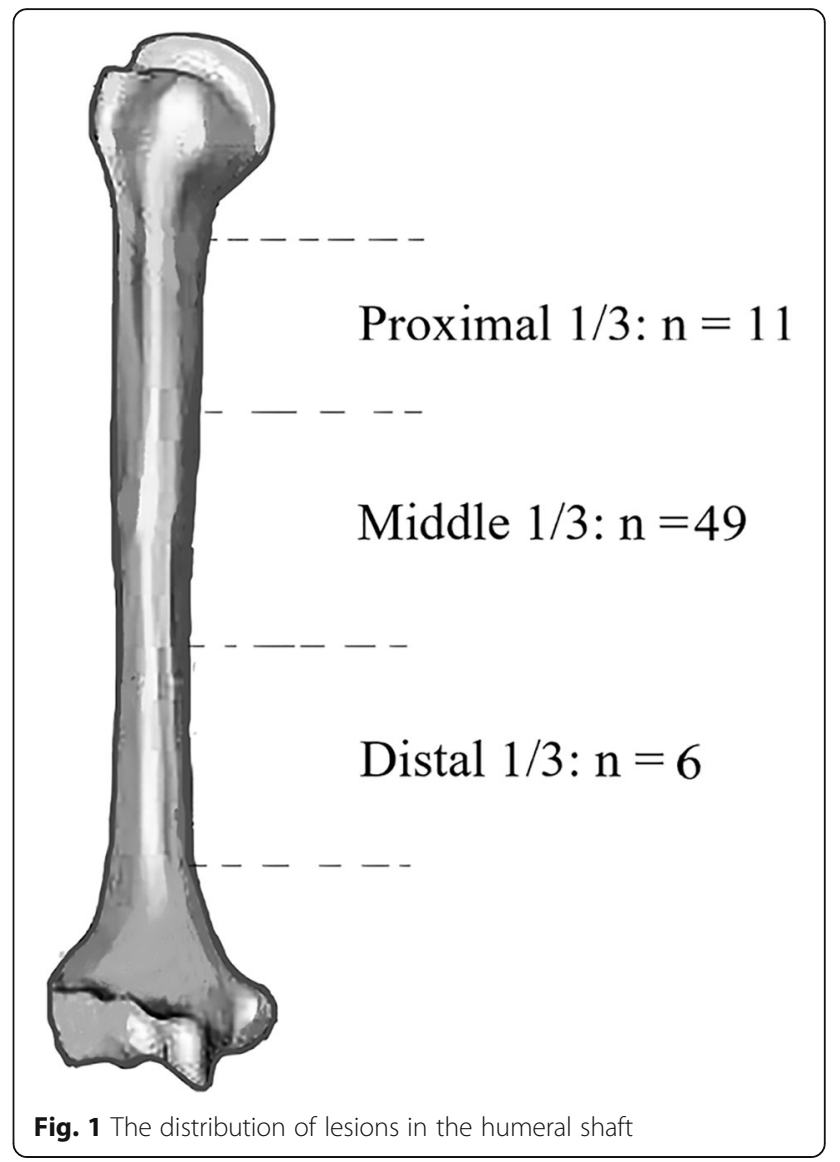

radiographs can be used to determine whether a very narrow intramedullary canal requiring plating is present. Our general indications for intercalary prosthetic replacement were solitary hypervascular metastatic lesions, lesions with large cortex destruction, and distinct soft tissue masses. The prerequisite for performing this procedure is that approximately $5 \mathrm{~cm}$ of the intramedullary canal remains after segmental resection at each end to accept the implant stem.

\section{Surgical technique \\ Intralesional procedure and reinforced osteosynthesis}

Most commonly, a brachialis-splitting approach was used to expose the anterior aspect of the humerus [25]. A cortical window was created through the area of bone destruction, and all of the gross tumors were completely curetted.

If the humerus was prepared to receive IMN, the entry point was made via the delta-split approach following the standard antegrade nail insertion technique [26]. An appropriately sized nail was inserted over a guide wire, and the length and fracture reduction of the entire humerus were verified. Then, the nail was locked proximally and distally to provide immediate rotational stability 
and avoid telescoping. Finally, polymethylmethacrylate containing gentamicin was added to the tumor cavity.

Before the plate was applied, reduction of the fracture and implantation of the internal fixation device were performed. The screws were removed temporarily, except for the screws at the proximal and distal ends of the plate. Additionally, bone cement was introduced into the proximal and distal fragments via a cement gun, and then, the removed screws were reinstalled before the cement hardened. Therefore, the intramedullary cement and the screws became a solid "reinforced concrete structure."

\section{Wide resection and segmental endoprosthesis reconstruction}

Wide intercalary resection of the humeral diaphyseal lesions was performed according to the Ennecking principle [27]. The proximal and distal canals were reamed to accommodate the stems. The prosthesis was manufactured using computer-aided design and manufacturing technologies after the level of humeral transection was determined (CHUNLi Corp., Beijing, China). Intraoperative fluoroscopy was used to monitor the reaming process to avoid penetration into the adjacent joint. Facing reamers were used to machine the proper radius of curvature of the exposed cortical bone to ensure a flush fit of the implant's stem-body junction. The intramedullary stems were simultaneously fixed at the proximal and distal bone stumps with cement via a cement gun. Then, the spacer was assembled in situ and connected using two locking bolts (Fig. 2).

\section{Postoperative treatment}

Palliative chemotherapy or targeted therapy was administered based on the specific tumor type and treatment protocol practiced at that time. External beam radiation was used or was planned for almost all intralesional surgical interventions. Generally, radiotherapy was implemented approximately 4 weeks postoperatively. Intravenous bisphosphonates were routinely used for all cases.

\section{Statistical analysis}

The data are presented as the mean \pm standard deviation (SD). Statistical analysis was performed using SPSS software version 22 (IBM Corp., Armonk, New York, USA). One-way ANOVA was utilized to assess the differences among the three groups in age, operating duration, blood loss, implant follow-up period, and functional scores. A post hoc test was then performed to evaluate the ANOVA results. The rates of complications among

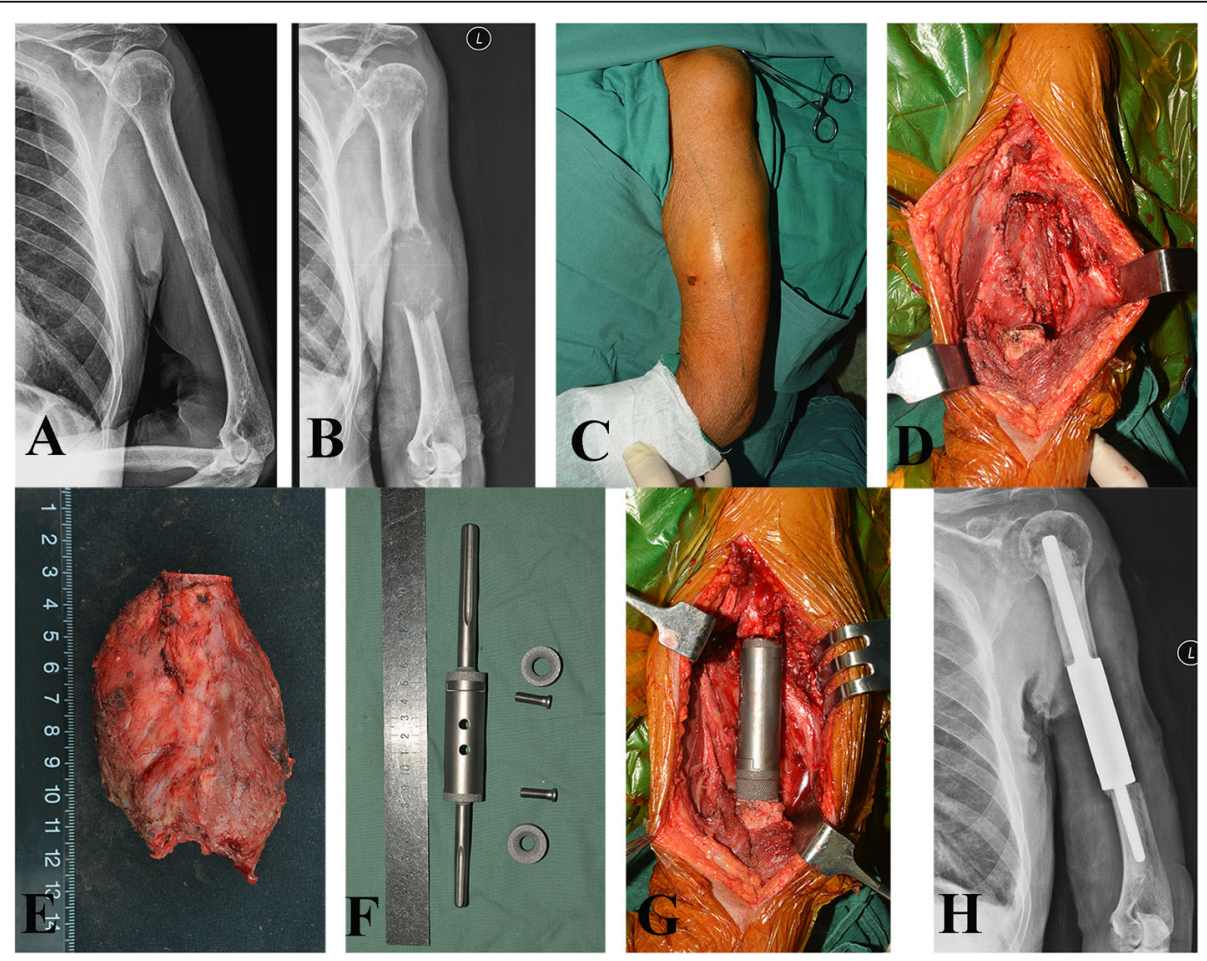

Fig. 2 Intercalary prosthetic reconstruction for a pathologic fracture of the left humeral shaft in patient 59, a 76-year-old male. a Anteroposterior radiograph of the left humerus showed osteolytic destruction in the middle 1/3 of the humerus. $\mathbf{b}$ The metastatic lesion of lung carcinoma was enlarged despite 3 months of conservative treatment. c The incision was made proximally through a deltopectoral approach and distally on the arm over the medial border of the biceps muscle. $\mathbf{d}$, e Intraoperative photos show that the lesion was resected widely. $\mathbf{f}$, $\mathbf{g}$ Intraoperative photos show the custom-made prosthesis. $\mathbf{h}$ Postoperative $\mathbf{X}$-ray images show that the prosthesis is in a good position 
the three groups were compared by the chi-square test (or Fisher's exact test).

\section{Results}

The average follow-up time was $20.3 \pm 18.4$ months (range, 3-75 months). The overall survival rate was $59.7 \%$ at 12 months and $46.7 \%$ at 24 months (Fig. 3). At the latest follow-up, 38 patients had died of tumor progression or visceral metastasis (Table 2).

Notably, $83.3 \%(15 / 18)$ of the patients with lung carcinoma and $77.8 \%(14 / 18)$ of those with myeloma underwent open reduction and osteosynthesis, while $54.5 \%(6 / 11)$ of the renal cell carcinoma patients underwent segmental resection. Five renal cell carcinoma patients and two thyroid carcinoma metastasis patients did not undergo intercalary prosthetic replacement because of the presence of multiple bone metastases.

The average resection length was $7.8 \pm 1.3 \mathrm{~cm}$ (range, $6-10 \mathrm{~cm}$ ) for patients in the prosthesis group. The mean operating duration and blood loss values of the patients treated with intercalary prostheses were smaller than those of the patients who underwent either IMN (116.5 vs. $135 \mathrm{~min}, p=0.169 ; 241.2$ vs. $539.4 \mathrm{ml}, p=0.03$ ) or PF (116.5 vs. $153.3 \mathrm{~min}, p=0.002 ; 241.2$ vs. $537.9 \mathrm{ml}, p$ $=0.012)$ (Table 3$)$.

Overall, 12 (12/63, 19\%) complications developed after surgery, and 6 of them were treated with another operation. No infections were found in this cohort of patients.

In the IMN group, one patient with painful shoulder impingement with functional limitations (patient no. 1) was managed by analgesics and did not undergo additional surgery. Two local recurrences (patient nos. 4 and 7) were observed, resulting in instability and pain. Consequently, patient 4 underwent wide tumor resection and total humeral prosthetic replacement. Patient 7 underwent curettage again and supplementary plate fixation in the distal humerus. In the PF group, temporary iatrogenic radial nerve palsy was found in three cases (patient nos. 14, 38, and 56); fortunately, two patients achieved neurologic recovery within 6 months, while one (patient 14) did not recover, and neurologic deficits remained until the patient's death. One mechanical failure that occurred 5 months after postoperative radiation (patient no. 12) was attributable to poor initial fixation, and revision surgery with a longer plate was performed (Fig. 4). Two local recurrences (patient nos. 25 and 60) were observed at 6 and 4 months, and both cases were successfully managed by additional resection and prosthetic replacement. Another local relapse (patient no. 54 ) in the PF group was not treated with another operation due to the deterioration of the patient's general status.

In the prosthetic group, one renal cancer patient (patient no. 23) developed local relapse in the proximal

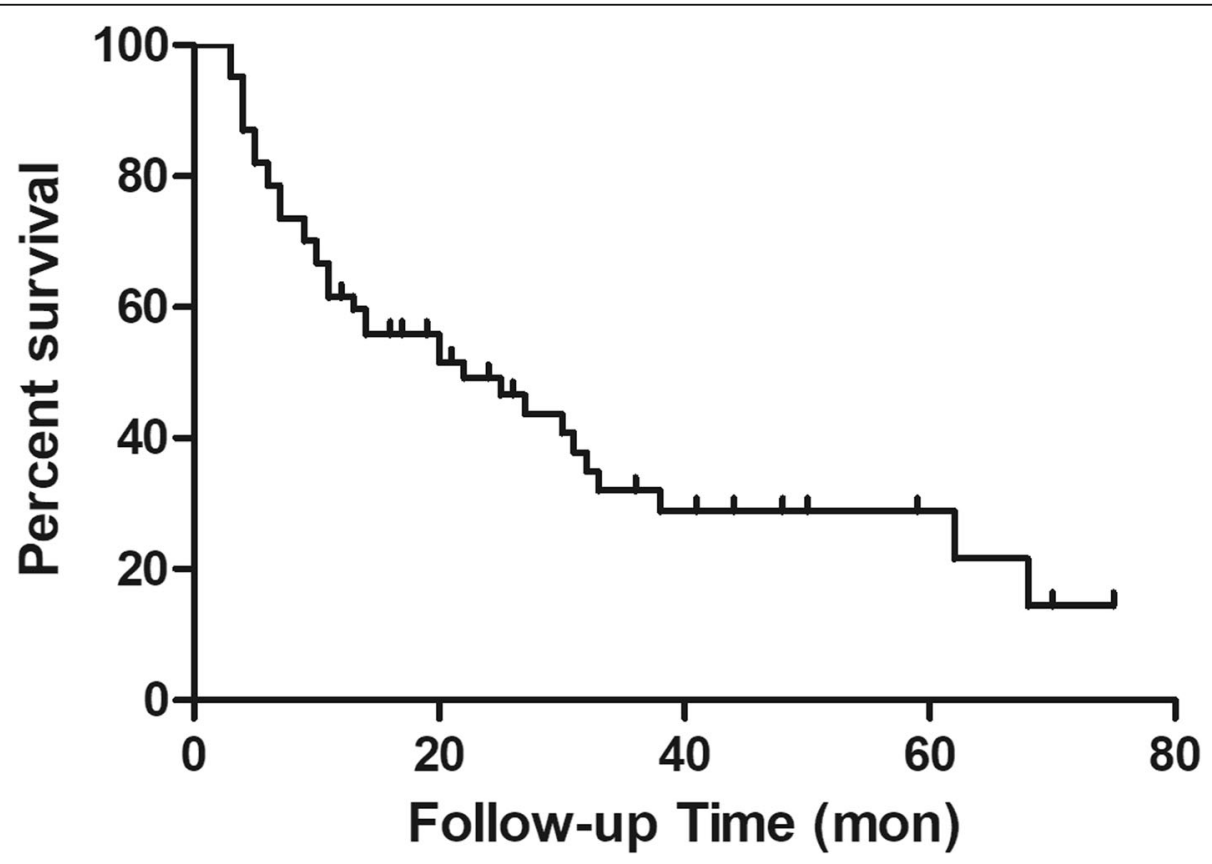

Fig. 3 The Kaplan-Meier curve of overall survival probability for all patients 
Table 2 Details of patient and tumor characteristics, complications, and functional outcomes

\begin{tabular}{|c|c|c|c|c|c|c|c|c|c|}
\hline No. & $\begin{array}{l}\text { Age/ } \\
\text { Gender }\end{array}$ & Primary tumor & Operation & $\begin{array}{l}\text { Operative } \\
\text { time (min) }\end{array}$ & $\begin{array}{l}\text { Estimated } \\
\text { blood loss (ml) }\end{array}$ & $\begin{array}{l}\text { Follow-up time } \\
\text { (month) }\end{array}$ & Complications & $\begin{array}{l}\text { MSTS } \\
\text { score }\end{array}$ & $\begin{array}{l}\text { ASES } \\
\text { score }\end{array}$ \\
\hline 1 & $68 / F$ & Lung cancer & IMN & 120 & 500 & 4 & $\begin{array}{l}\text { Shoulder joint } \\
\text { impingement }\end{array}$ & 19 & 63 \\
\hline 2 & $78 / \mathrm{M}$ & Lymphoma & IMN & 170 & 600 & 36 & & 25 & 83 \\
\hline 3 & $80 / F$ & Myeloma & IMN & 130 & 500 & 5 & & 21 & 70 \\
\hline 4 & $72 / \mathrm{M}$ & Renal cancer & IMN & 180 & 2500 & 62 & LR (11 months) & 24 & 80 \\
\hline $5 a$ & $65 / F$ & Myeloma & IMN & 100 & 200 & 30 & & 24 & 80 \\
\hline $5 b$ & & & IMN & 110 & 300 & & & 21 & 70 \\
\hline 6 & $75 / F$ & Lung cancer & PF & 95 & 400 & 7 & & 21 & 70 \\
\hline $7 a$ & $62 / M$ & Myeloma & IMN & 90 & 200 & 4 & & 20 & 67 \\
\hline $7 b$ & & & IMN & 115 & 230 & & LR/FX (1 month) & 21 & 70 \\
\hline 8 & 70/M & Lung cancer & PF & 95 & 300 & 6 & & 23 & 77 \\
\hline 9 & $55 / M$ & Unknown & IMN & 135 & 700 & 3 & & 24 & 80 \\
\hline 10 & $45 / M$ & Gastric cancer & IMN & 105 & 550 & 5 & & 21 & 70 \\
\hline 11 & $40 / \mathrm{M}$ & Lung cancer & IMN & 125 & 650 & 7 & & 23 & 77 \\
\hline 12 & $53 / \mathrm{M}$ & Lung cancer & PF & 145 & 300 & 9 & $\begin{array}{l}\text { Screw breakage } \\
(5 \text { months })\end{array}$ & 20 & 67 \\
\hline 13 & $44 / F$ & $\begin{array}{l}\text { Malignant peripheral } \\
\text { schwannoma }\end{array}$ & PF & 140 & 1600 & 13 & & 22 & 73 \\
\hline 14 & $71 / M$ & Lung cancer & PF & 155 & 400 & 4 & $\mathrm{RNI}$ & 20 & 67 \\
\hline 15 & $47 / F$ & Breast cancer & PF & 150 & 200 & 13 & & 23 & 77 \\
\hline 16 & $79 / M$ & - Prostate cancer & PF & 135 & 300 & 14 & & 22 & 73 \\
\hline 17 & $52 / \mathrm{M}$ & Lung cancer & PF & 205 & 200 & 5 & & 26 & 87 \\
\hline 18 & $47 / F$ & Cervical cancer & PF & 115 & 400 & 9 & & 25 & 83 \\
\hline 19 & $66 / F$ & Myeloma & PF & 80 & 800 & 10 & & 20 & 67 \\
\hline 20 & $58 / F$ & Lung cancer & Prosthesis & 105 & 150 & 6 & & 24 & 80 \\
\hline $21 a$ & $53 / F$ & $\begin{array}{l}\text { Malignant peripheral } \\
\text { schwannoma }\end{array}$ & IMN & 100 & 150 & 3 & & 20 & 67 \\
\hline $21 b$ & & & IMN & 90 & 100 & & & 21 & 70 \\
\hline 22 & $76 / F$ & Renal cancer & Prosthesis & 150 & 300 & 70 & & 20 & 67 \\
\hline 23 & $60 / M$ & Renal cancer & Prosthesis & 95 & 400 & 75 & LR (48 months) & 20 & 67 \\
\hline 24 & $75 / M$ & Renal cancer & Prosthesis & 100 & 100 & 68 & & 23 & 77 \\
\hline 25 & $61 / \mathrm{M}$ & Lung cancer & PF & 245 & 800 & 10 & $\begin{array}{l}\text { LR/Fixation failure } \\
\text { (6 months) }\end{array}$ & 22 & 73 \\
\hline 26 & $43 / M$ & Unknown & Prosthesis & 95 & 100 & 11 & & 22 & 73 \\
\hline 27 & $49 / F$ & Myeloma & PF & 120 & 200 & 59 & & 25 & 83 \\
\hline 28 & $60 / M$ & Renal cancer & PF & 150 & 200 & 22 & & 23 & 77 \\
\hline 29 & $71 / F$ & Breast cancer & Prosthesis & 195 & 150 & 33 & $\begin{array}{l}\text { Aseptic loosening } \\
\text { (36 months) }\end{array}$ & 20 & 67 \\
\hline 30 & $70 / F$ & Myeloma & PF & 110 & 300 & 24 & & 25 & 83 \\
\hline 31 & $65 / M$ & Lung cancer & Prosthesis & 120 & 200 & 4 & & 25 & 83 \\
\hline 32 & $50 / F$ & Myeloma & Prosthesis & 100 & 100 & 20 & & 24 & 80 \\
\hline 33 & $45 / F$ & Myeloma & Prosthesis & 100 & 500 & 48 & & 26 & 87 \\
\hline 34 & $78 / \mathrm{M}$ & Pancreatic cancer & Prosthesis & 65 & 200 & 14 & & 20 & 67 \\
\hline 35 & $60 / M$ & Renal cancer & Prosthesis & 120 & 300 & 31 & & 23 & 77 \\
\hline 36 & $78 / F$ & Thyroid cancer & PF & 165 & 800 & 41 & & 24 & 80 \\
\hline 37 & $61 / F$ & Breast cancer & Prosthesis & 135 & 100 & 50 & & 24 & 80 \\
\hline
\end{tabular}


Table 2 Details of patient and tumor characteristics, complications, and functional outcomes (Continued)

\begin{tabular}{|c|c|c|c|c|c|c|c|c|c|}
\hline No. & $\begin{array}{l}\text { Age/ } \\
\text { Gender }\end{array}$ & Primary tumor & Operation & $\begin{array}{l}\text { Operative } \\
\text { time (min) }\end{array}$ & $\begin{array}{l}\text { Estimated } \\
\text { blood loss (ml) }\end{array}$ & $\begin{array}{l}\text { Follow-up time } \\
\text { (month) }\end{array}$ & Complications & $\begin{array}{l}\text { MSTS } \\
\text { score }\end{array}$ & $\begin{array}{l}\text { ASES } \\
\text { score }\end{array}$ \\
\hline 38 & $62 / F$ & Thyroid cancer & PF & 160 & 500 & 38 & $\mathrm{RNI}$ & 19 & 63 \\
\hline 39 & $66 / \mathrm{M}$ & Myeloma & PF & 190 & 350 & 25 & & 22 & 73 \\
\hline 40 & $60 / F$ & Lung cancer & PF & 190 & 500 & 44 & & 20 & 67 \\
\hline 41 & $66 / M$ & Myeloma & PF & 125 & 650 & 20 & & 23 & 77 \\
\hline 42 & $39 / F$ & Breast cancer & PF & 135 & 800 & 32 & & 24 & 80 \\
\hline 43 & $61 / F$ & Myeloma & Prosthesis & 90 & 200 & 26 & & 26 & 87 \\
\hline 44 & $52 / \mathrm{M}$ & Renal cancer & PF & 200 & 1000 & 27 & & 23 & 77 \\
\hline 45 & $66 / F$ & Renal cancer & PF & 180 & 600 & 17 & & 25 & 83 \\
\hline 46 & $73 / \mathrm{M}$ & Myeloma & PF & 140 & 100 & 4 & & 26 & 87 \\
\hline 47 & $65 / F$ & Lung cancer & PF & 160 & 700 & 26 & & 23 & 77 \\
\hline 48 & $68 / F$ & Myeloma & IMN & 230 & 300 & 24 & & 26 & 87 \\
\hline 49 & $60 / M$ & Renal cancer & PF & 185 & 150 & 13 & & 22 & 73 \\
\hline 50 & $62 / M$ & Myeloma & PF & 180 & 1200 & 21 & & 21 & 70 \\
\hline 51 & $59 / F$ & Myeloma & PF & 140 & 1000 & 21 & & 25 & 83 \\
\hline 52 & $63 / M$ & Renal cancer & Prosthesis & 160 & 300 & 11 & & 22 & 73 \\
\hline 53 & $68 / \mathrm{M}$ & Myeloma & PF & 190 & 1200 & 19 & & 21 & 70 \\
\hline 54 & $59 / \mathrm{M}$ & Lung cancer & PF & 180 & 200 & 7 & LR (4 months) & 22 & 73 \\
\hline 55 & $57 / \mathrm{M}$ & Lung cancer & PF & 150 & 300 & 16 & & 21 & 70 \\
\hline 56 & $57 / F$ & Rectal cancer & PF & 180 & 200 & 11 & RNI & 22 & 73 \\
\hline 57 & $52 / F$ & Myeloma & IMN & 120 & 550 & 12 & & 21 & 70 \\
\hline 58 & $67 / F$ & Lung cancer & IMN & 240 & 600 & 11 & & 24 & 80 \\
\hline 59 & $76 / \mathrm{M}$ & Lung cancer & Prosthesis & 90 & 200 & 3 & & 24 & 80 \\
\hline 60 & 73/M & Lung cancer & PF & 170 & 900 & 4 & LR (3 months) & 25 & 83 \\
\hline 61 & $82 / \mathrm{M}$ & Gallbladder carcinoma & PF & 100 & 200 & 6 & & 24 & 80 \\
\hline 62 & $62 / M$ & Renal cancer & Prosthesis & 150 & 500 & 3 & & 24 & 80 \\
\hline 63 & $69 / F$ & Myeloma & Prosthesis & 110 & 300 & 3 & & 25 & 83 \\
\hline
\end{tabular}

Patients $5(a, b), 7(a, b)$, and $21(a, b)$ each had bilateral humerus fractures

$M$ male, $F$ female, IMN intramedullary nail, $P F$ plate fixation, $L R$ local recurrence, $F X$ fracture, $R N I$ radial nerve injury, ASES American Shoulder and Elbow Surgeons, MSTS Musculoskeletal Tumor Society

Table 3 Comparisons among three groups

\begin{tabular}{|c|c|c|c|c|c|c|}
\hline Variables & IMN $(n=16)$ & $\operatorname{PF}(n=33)$ & Prosthesis $(n=17)$ & $P 1$ value & $P 2$ value & $P 3$ value \\
\hline Mean age (yrs) & $61.9 \pm 12.2$ & $62.1 \pm 10.5$ & $63.1 \pm 10.5$ & $0.969^{*}$ & $0.766^{*}$ & $0.745^{*}$ \\
\hline Follow-up time (mon) & $20.8 \pm 24.0$ & $18.1 \pm 13.1$ & $28.0 \pm 25.3$ & $0.666^{*}$ & $0.321^{*}$ & $0.093^{*}$ \\
\hline Mean operative time (min) & $135 \pm 46.4$ & $153.3 \pm 36.8$ & $116.5 \pm 32.2$ & $0.121^{*}$ & $0.169^{*}$ & $0.002^{*}$ \\
\hline Mean blood loss (ml) & $539.4 \pm 558.5$ & $537.9 \pm 370.8$ & $241.2 \pm 131.4$ & $0.990^{*}$ & $0.030^{*}$ & $0.012^{*}$ \\
\hline Mean ASES score & $74.0 \pm 6.9$ & $75.6 \pm 6.3$ & $76.9 \pm 6.8$ & $0.419^{*}$ & $0.206^{*}$ & $0.511^{*}$ \\
\hline Mean MSTS score & $22.2 \pm 2.1$ & $22.7 \pm 1.9$ & $23.1 \pm 2.1$ & $0.405^{*}$ & $0.214^{*}$ & $0.555^{*}$ \\
\hline Complication rate & $3 / 16$ & $7 / 33$ & $2 / 17$ & $1.000+$ & $1.000+$ & $1.000+$ \\
\hline
\end{tabular}

$P 1$ : The difference between IMN and PF

$P 2$ : The difference between IMN and SDR prosthesis

$P 3$ : The difference between PF and SDR prosthesis

*: Post hoc test

t: Fisher's exact test

MSTS Musculoskeletal Tumor Society 


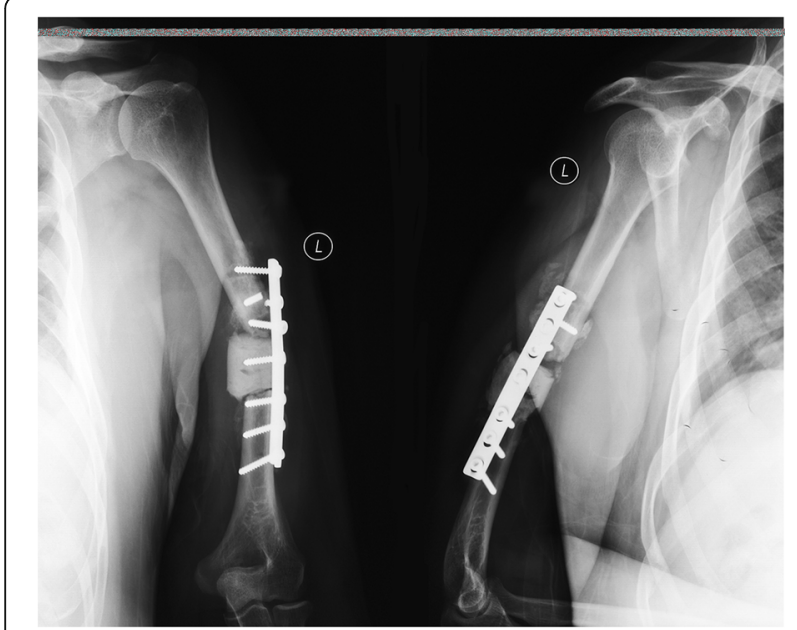

Fig. 4 The $X$-ray film taken 5 months after the initial operation showed plate fixation failure, and revision surgery was performed humerus 4 years after surgery, and revision with a modular proximal humeral prosthesis was performed (Fig. 5). Another case of aseptic loosening (patient no. 29 ) that occurred 3 years postoperatively was not treated with additional surgery since a brain metastasis was detected simultaneously (Fig. 6).

At the final follow-up, the mean postoperative upper extremity MSTS scores in the IMN, PF, and prosthetic groups were $22.2 \pm 2.1,22.7 \pm 1.9$, and $23.1 \pm 2.1$, respectively, and the mean postoperative ASES scores were $74.0 \pm 6.9,75.5 \pm 6.4$, and $76.9 \pm 6.8$, respectively. Oneway ANOVA and post hoc analysis did not show any significant differences in functional scores among the three groups.

\section{Discussion}

Currently, prompt pain relief, rapid functional restoration, and good local tumor control are mandatory for most patients with pathologic fractures of the humeral diaphysis, and the use of surgical stabilization will most likely be used more widely in the future. Various surgical options have been described in the literature, with their

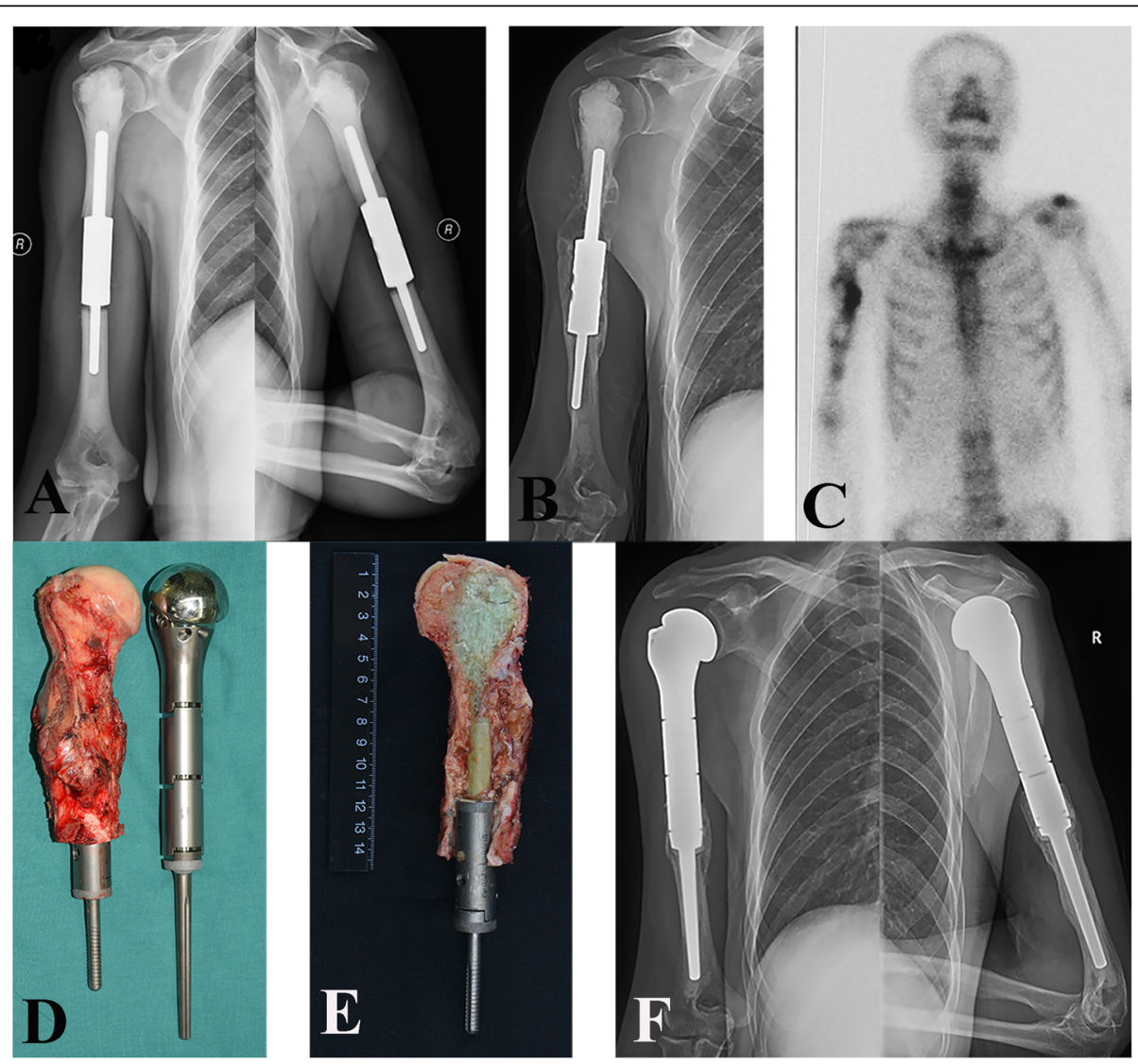

Fig. 5 a Postoperative radiographs of a 60-year-old man who underwent segmental resection and reconstruction by using a cemented custommade segmental prosthesis. $\mathbf{b}, \mathbf{c}$ The $\mathrm{X}$-ray and bone scintigraphy scan taken 48 months show local relapse proximal to the humerus and loosening of the distal stem. $\mathbf{d}$, e The intraoperative pictures showed a lesion at the proximal humerus, and then, revision with a modular proximal humeral prosthesis was performed. $\mathbf{f}$ The postoperative image shows that the position of the prosthesis is satisfactory 


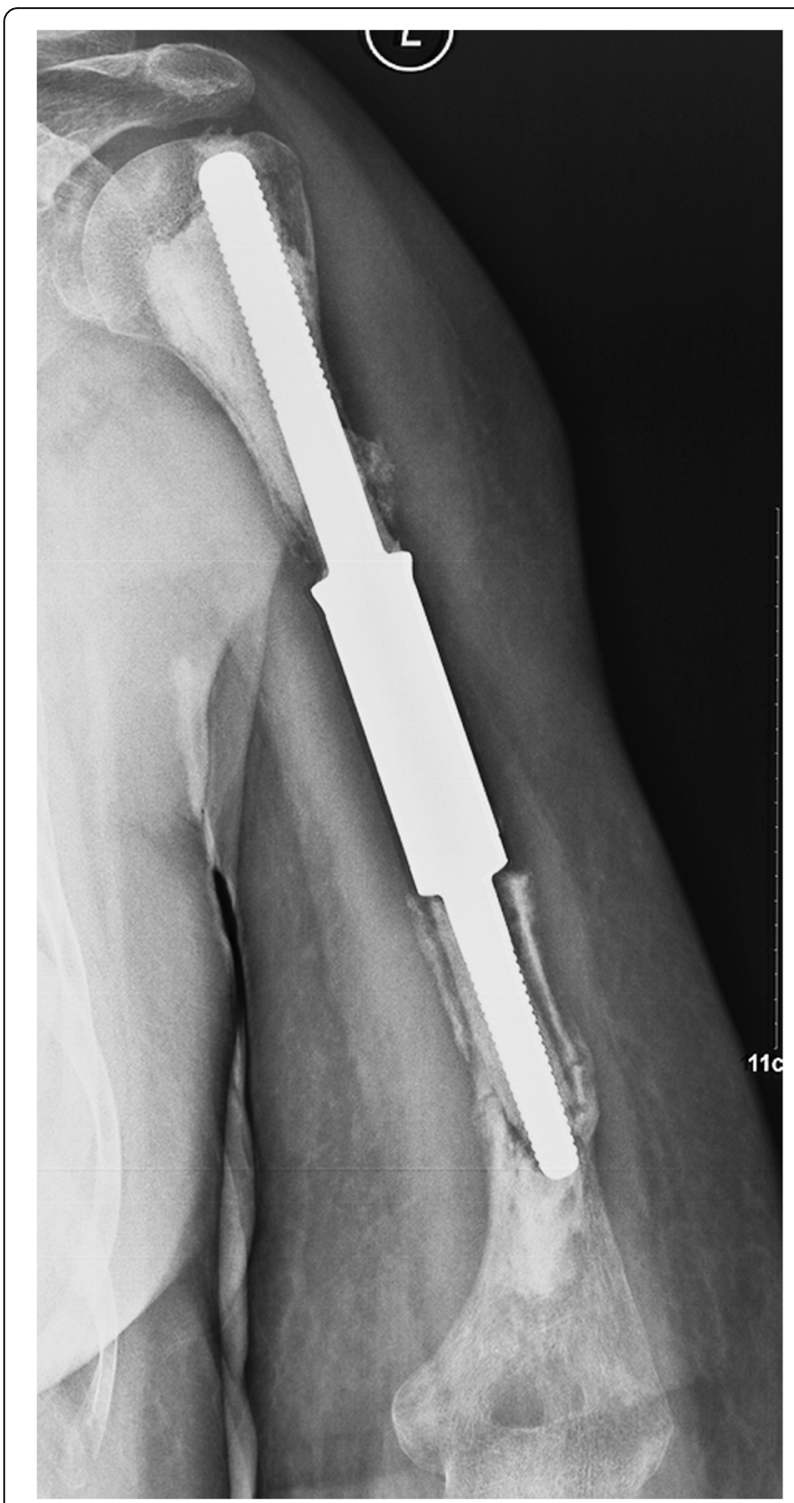

Fig. 6 The postoperative radiograph taken 3 years after surgery shows loosening in the distal stem of the prosthesis caused by overuse; however, the function of this limb is still acceptable. The patient did not receive additional surgical management due to the presence of a brain metastasis

inherent advantages and disadvantages. The current study presents the results of 66 humerus diaphysis fractures treated with IMN, PF, and intercalary prostheses, aiming to clarify the existing problems and to optimize the treatment strategies. The findings of this study support our hypothesis that prosthetic replacement reduces the operative time, intraoperative blood loss, and postoperative complications more than IMN or PF does and leads to acceptable functional levels.

In this study, the average follow-up time was 20.3 months (range, 3-75 months). A total of $59.7 \%$ of the patients lived for more than 1 year, and $46.7 \%$ lived for more than 2 years. Prior studies have reported 12-month survival rates of $16 \%$ [15], 24\% [28], 40\% [29], and $88 \%$ [30]. The differences in primary tumors, stage of the disease, number of impending fractures, and selection criteria may explain the differences in the survival rate across studies. In this study, we included patients with myeloma or tumors with better prognoses (breast carcinoma, myeloma, renal cell carcinoma, etc.).

Intramedullary nailing, either with or without tumor removal, has been frequently adopted in previous studies $[7,10,12]$, although the closed method has the main disadvantage of leaving the tumor mass in situ and making tumor cells spread throughout the medullary cavity. We also performed closed IMN for three patients with bilateral humeral shaft fractures and poor survival estimation. Most patients in this cohort underwent open osteosynthesis with bone cement to enhance the construct and enable patients to withstand the stresses of immediate motions. Intercalary prostheses have been commercially available since 2012, and we started to put use them in clinical practice for select cases. Segmental resection does not require intralesional tumor curettage, and the main blood vessels surrounding the tumor can be ligated before resection. We found that the open IMN and PF groups required longer operation times and had larger volumes of intraoperative hemorrhage due to the intralesional procedure, which is in agreement with the following results reported by Capanna et al. [31]: the "intralesional procedure involving a wide exposure, curettage, filling with cement, and osteosynthesis has no significant merits regarding operating time, blood loss, and recovery time compared with a 'more aggressive' wide resection and reconstruction with a prosthesis."

Twelve postoperative complications were noted in this series. Shoulder movement restrictions after IMN were found in one patient because the extent of antegrade nailing was inadequate. One case of plate failure occurred and was resolved by replating; therefore, we believe that poor initial fixation might have been avoided if a longer plate had been used. This is an example of the many pitfalls of incorrectly using locking plate technology. Compared with prosthetic replacement, the osteosynthetic method generally provides partly local tumor control. All local tumor recurrences in the patients who underwent IMN and PF fixation developed within 1 year in this study. The incidence of iatrogenic radial nerve injury after plate fixation for humerus fractures varies widely and ranges from 6 to $16 \%$ [28, 29, 32, 33]. In this study, 3 (9.1\%) nerve injuries developed on account of extensive soft-tissue stripping in patients in the PF group with lesions located at the middle-lower $1 / 3$ of the humerus, and this condition tended to lead to radial nerve injury. We are not sure whether iatrogenic radial nerve palsy could have been avoided had we chosen to 
perform retrograde IMN. In the procedure of intercalary prosthetic replacement, we were inclined to shorten the humerus by appropriately 1 to $2 \mathrm{~cm}$ to decrease the risk of overstretch injury to the radial nerve and to obtain better soft tissue coverage for the prosthesis. None of the patients in this group experienced nerve palsy.

It is unclear whether IMN leads to better outcomes than does PF. In a study conducted by Wedin et al., intramedullary nails failed in $7 \%$ of patients, and plate fixation failed in 22\% [34]. However, Dijkstra et al. found that IMN and plate fixation yielded similar results [15]. In the present study, the incidence of postoperative complications in the IMN group was $18.8 \%(3 / 16)$ and $21.2 \%(7 / 33)$ in the PF group, which were in the range of reported incidence rates in previous studies $[8,9,13-15$, 19, 20, 28, 34-36] (Table 4).

Admittedly, the use of prostheses cannot prevent the occurrence of complications in the long term. Aseptic loosening of the prosthetic stem occurred in a prolonged breast cancer survivor, possibly due to overuse of the involved upper limb. Another renal cell carcinoma patient experienced local tumor recurrence 4 years after the operation.

Abudu et al. concluded that the possibility of early loosening is higher when the intramedullary fixation length of the intercalary prosthesis is shorter than $5 \mathrm{~cm}$ [11]. To avoid this problem, we applied an additional extracortical plate in one patient with a distal stem of 4

Table 4 Comparison of current study results with those of other studies involving intercalary endoprostheses

\begin{tabular}{|c|c|c|c|c|c|c|}
\hline Author, year & $\begin{array}{l}\text { Case } \\
\text { number }\end{array}$ & $\begin{array}{l}\text { Average age } \\
\text { (years) }\end{array}$ & Treatment & Complication & $\begin{array}{l}\text { Mean follow-up } \\
\text { time (months) }\end{array}$ & $\begin{array}{l}\text { Mean MSTS } \\
(\%)\end{array}$ \\
\hline \multirow[t]{2}{*}{ Dijkstra et al. [15], 1996} & 38 & 65 & IMN (18) & $\begin{array}{l}\text { Fracture: } 1 \\
\text { Instability: } 2\end{array}$ & / & / \\
\hline & & & PF (20) & $\begin{array}{l}\text { Wound problem: } 2 \\
\text { Nerve injury: } 1 \\
\text { Local recurrence: } 1\end{array}$ & / & / \\
\hline Ofluoglu et al. [9], 2009 & 24 & 63 & IMN & Loosening: 2 & / & / \\
\hline \multirow[t]{2}{*}{ Sarahrudi et al. [28], 2009} & 41 & 66.3 & IMN (19) & $\begin{array}{l}\text { Instability: } 2 \\
\text { Tumor progression: } 1\end{array}$ & / & / \\
\hline & & 70.2 & PF (22) & $\begin{array}{l}\text { RNI: } 4 \\
\text { Fracture: } 1 \\
\text { Loosening: } 1\end{array}$ & / & / \\
\hline Ruggieri et al. [36], 2011 & 8 & / & Prosthesis & Loosening: 1 & 25 & 90 \\
\hline McGrath et al. [8], 2011 & 13 & 35 & Endoprosthesis & $\begin{array}{l}\text { Local recurrence: } 2 \\
\text { Loosening: } 4 \\
\text { Fracture: } 2 \\
\text { Nerve injury: } 2\end{array}$ & 57 & 77 \\
\hline Laitinen et al. [35], 2011 & 40 & 65 & IMN & $7(18 \%)$ & / & $70 / 68$ \\
\hline \multirow[t]{2}{*}{ Wedin et al. [34], 2012} & 128 & / & IMN (117) & $\begin{array}{l}\text { Fracture: } 1 \\
\text { Nonunion: } 5 \\
\text { Infection: } 2\end{array}$ & / & / \\
\hline & & / & PF (11) & Fracture: 2 & / & / \\
\hline Benevenia et al. [13], 2016 & 18 & 69 & Prosthesis & None & 10 & 83 \\
\hline Zhao et al. [19], 2018 & 9 & 63 & Prosthesis & $\begin{array}{l}\text { RNI: } 1 \\
\text { Aseptic loosening: } 1\end{array}$ & 9 & 85 \\
\hline Casadei et al. [14], 2018 & 12 & 67 & IMN & $\begin{array}{l}\text { Infection: } 1 \\
\text { Local recurrence: } 1 \\
\text { Loosening: } 2\end{array}$ & / & 63 \\
\hline Zheng et al. [20], 2019 & 13 & / & Prosthesis & $\begin{array}{l}\text { RNI: } 2 \\
\text { Aseptic loosening: } 2\end{array}$ & 11 & 65 \\
\hline \multirow[t]{3}{*}{ Current study } & 66 & 62 & IMN (16) & $\begin{array}{l}\text { Local recurrence: } 2 \\
\text { Rotator cuff injury: } 1\end{array}$ & 21 & 74 \\
\hline & & 61 & PF (33) & $\begin{array}{l}\text { RNI: } 3 \\
\text { Local recurrence: } 3 \\
\text { Screw break: } 1\end{array}$ & 18 & 76 \\
\hline & & 63 & Prosthesis (17) & $\begin{array}{l}\text { Local recurrence: } 1 \\
\text { Aseptic loosening: } 1\end{array}$ & 28 & 77 \\
\hline
\end{tabular}


$\mathrm{cm}$ to reduce mechanical torsional stresses at the bonestem interface (Fig. 7).

Ruggieri et al. [36] presented 8 cases with metastatic humeral lesions treated with intercalary prostheses. The mean follow-up time was 24.9 months (range, 7-50), and only one case of mechanical loosening was found at 30 months. Benevenia et al. [13] applied 17 intercalary endoprostheses for metastatic humeral shaft lesions, and there were no complications during the 9.5-month follow-up period. The authors recommended that the use of intercalary endoprostheses is a reasonable alternative to consider.

We observed that the average MSTS and ASES scores, indicating function, of the intercalary prosthetic replacement patients were 23.1 and 76.9 , respectively, and these values were comparable to those of the IMN and PF groups. Overall, intercalary prosthetic replacement seemed to yield acceptable levels of function and better local disease control, most notably with respect to the reduced postoperative time and blood loss.

In recent years, an increasing number of studies have reported different reconstructive strategies for humeral diaphysis metastases with varied outcomes, depending on the experience of each team $[1,7,10$, $11,13,14,18,19]$. The optimal implant choice requires the consideration of both patient- and surgeon-controlled factors. Surgical treatment is usually tailored on a patient-to-patient basis taking into account certain standard recommendations. Most patients are still treated with IMN or plates according to published studies [15, 28, 29], and the present study corroborates this trend: most patients (74.2\%) underwent osteosynthesis, but intercalary prostheses were also used. Admittedly, the indications for these three surgical procedures were not mutually exclusive. Fewer complications and better functional outcomes will be obtained when surgical indications are followed correctly, leading to marked improvement in patient quality of life. In order to individualize the treatment (IMN, PF, or prosthesis) to different humeral metastasis, we formulate a pathway that may help us to choose the surgical technique (Fig. 8).

Some limitations of this study require discussion. First, this was an observational case series study, and due to its retrospective and nonrandomized nature, selective bias and confounding bias may have been present in the study. Second, the type of resection and reconstruction was affected by the year of treatment and by patient and tumor factors. The intercalary prosthesis became available after 2012, and to some extent, patients with better prognoses were more likely to undergo segmental prostheses. Thus, comparative conclusions may not be appropriate. We believe that additional randomized prospective studies comparing these techniques may get

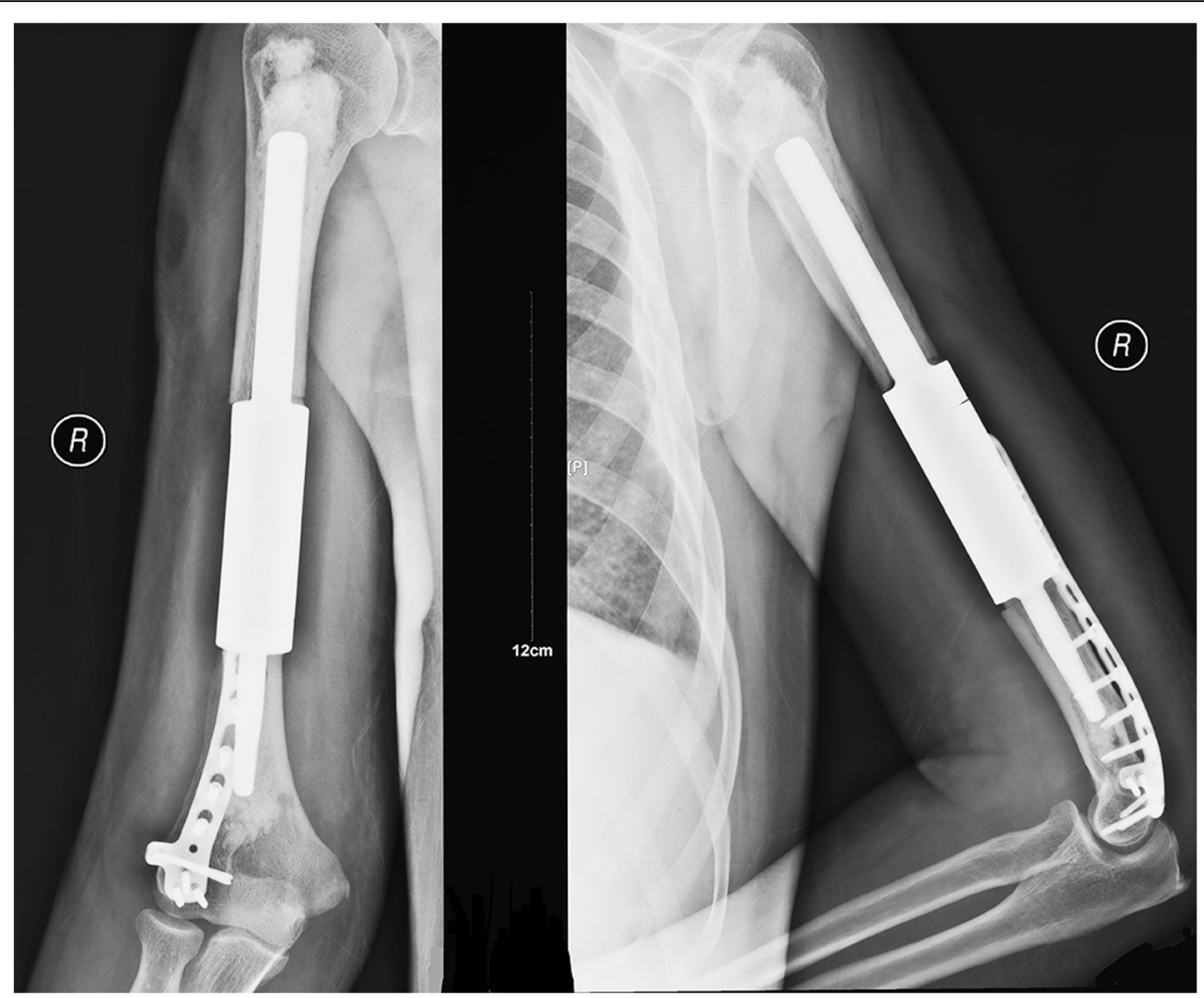

Fig. 7 The postoperative $X$-ray film shows that an additional extracortical plate was applied when the fixation length was less than $5 \mathrm{~cm}$ 


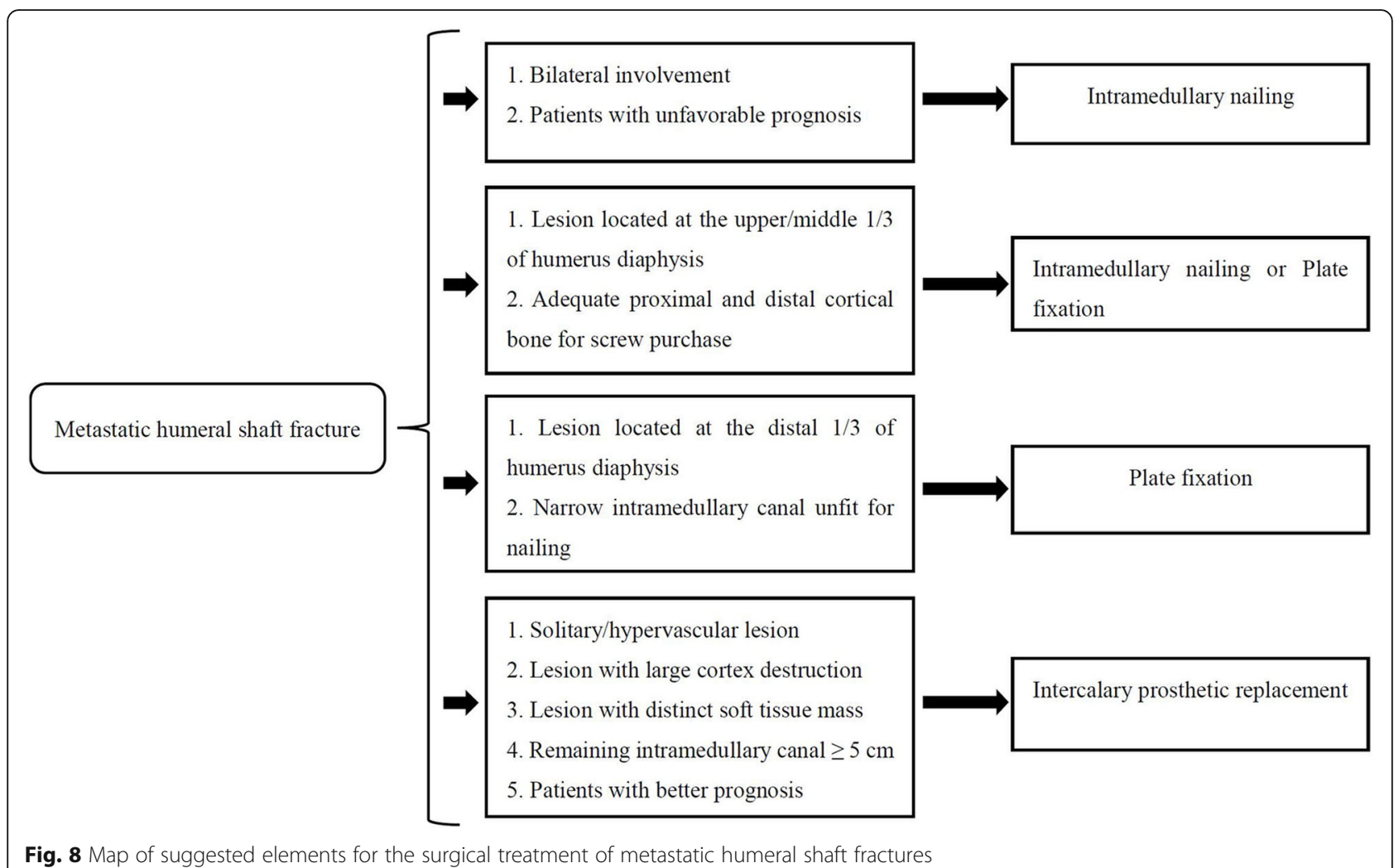

more convincing results. Nonetheless, even with these limitations, our results may be useful.

\section{Conclusion}

Three stabilization methods are effective in the treatment of humeral diaphysis metastatic lesions. Compared with IMN and PF, segmental endoprosthesis replacement may provide a construct associated with a shorter operative duration, less blood loss, lower complication rates, and comparable functional results. It may serve as an optimal stabilization method in exceptional situations with extensive cortical destruction or widespread softtissue extension or for those patients with better prognosis. Intercalary prostheses will most likely be used more widely in the future.

\section{Abbreviations}

IMN: Intramedullary nailing; PF: Plate fixation; KPS: Karnofsky

performance score; VAS: Visual analogue scale; ASES: American Shoulder and Elbow Surgeons; MSTS: Musculoskeletal Tumor Society; SD: Standard deviation

\section{Supplementary Information}

The online version contains supplementary material available at https://doi. org/10.1186/s12957-021-02250-1.

Additional file 1: Table I. The additional details of patients.
Authors' contributions

ZQZ: collecting the data, analyzing the data, preparing the manuscript. ZPY: collecting the data, analyzing the data, preparing the manuscript. TQY: designing the study, analyzing the data, preparing the manuscript, supervision. XDT: collecting the data, preparing the manuscript. WG: collecting the data, preparing the manuscript. RLY: collecting the data, preparing the manuscript. All authors read and approved the final manuscript.

\section{Funding}

The Capital's Funds for Health Improvement and Research (No. 2020-2-4085) will support the publication fees without affecting the diagnosis and treatment of patients, and the writing of manuscript.

\section{Availability of data and materials}

The datasets used and/or analyzed during the current study are available from the corresponding author on reasonable request.

\section{Declarations}

Ethics approval and consent to participate

The implementation of this study was approved by the Ethics Review Committee (ERC) of Peking University People's Hospital (2020PHB148-01) and informed consents from all subjects were waived.

Consent for publication

Informed written consent was obtained from the volunteer to publish their personal details information.

The authors declare that they have no competing interests. 
Received: 30 October 2020 Accepted: 21 April 2021

Published online: 05 May 2021

\section{References}

1. Frassica FJ, Frassica DA. Evaluation and treatment of metastases to the humerus. Clin Orthopaedics Related Res. 2003;415:212-8.

2. Wedin R, Bauer H. P: Failures after operation for skeletal metastatic lesions of long bones. Clin Orthopaedics Related Res. 1999;358:128-39.

3. Habermann ET, Lopez RA. Metastatic disease of bone and treatment of pathological fractures. Orthop Clin North Am. 1989;20(3):469-86.

4. Gainor BJ, Buchert P. Fracture healing in metastatic bone disease. Clin Orthop Relat Res. 1983;178:297-302.

5. Perez CA, Bradfield JS, Morgan HC. Management of pathologic fractures. Cancer. 1972;29(3):684-93. https://doi.org/10.1002/1097-0142(197203)29:3< 684::AID-CNCR2820290322>3.0.CO;2-K.

6. Harrington KD, Sim FH, Enis JE, Johnston JO, Diok HM, Gristina AG. Methylmethacrylate as an adjunct in internal fixation of pathological fractures. Experience with three hundred and seventy-five cases. J Bone Joint Surg Am. 1976;58(8):1047-55. https://doi.org/10.2106/00004623-1 97658080-00001.

7. Kim Yl, Kang HG, Kim JH, Kim SK, Lin PP, Kim HS. Closed intramedullary nailing with percutaneous cement augmentation for long bone metastases. Bone Joint J. 2016;98-B(5):703-9. https://doi.org/10.1302/03 01-620X.98B5.35312

8. McGrath A, Sewell MD, Hanna SA, Pollock RC, Skinner JA, Cannon SR, et al. Custom endoprosthetic reconstruction for malignant bone disease in the humeral diaphysis. Acta Orthop Belg. 2011;77(2):171-9.

9. Ofluoglu O, Erol B, Ozgen Z, Yildiz M. Minimally invasive treatment of pathological fractures of the humeral shaft. Int Orthop. 2009;33(3):707-12. https://doi.org/10.1007/s00264-008-0540-0.

10. Schwabe $\mathrm{P}_{1}$., Ruppert M, ., Tsitsilonis S, ., Melcher I, K-D Schaser, S Märdian Surgical management and outcome of skeletal metastatic disease of the humerus. Acta Chir Orthop Traumatol Cech 2014, 81:365-370, 6

11. Abudu A, Carter SR, Grimer RJ. The outcome and functional results of diaphyseal endoprostheses after tumour excision. J Bone Joint Surg Br. 1996;78:652-7

12. Baltov A, Mihail R, Dian E. Complications after interlocking intramedullary nailing of humeral shaft fractures. Injury-Int J Care Injured. 2014;45:S9-S15. https://doi.org/10.1016/j.injury.2013.10.044.

13. Benevenia J, Kirchner R, Patterson F, Beebe K, Wirtz DC, Rivero S, et al. Outcomes of a modular intercalary endoprosthesis as treatment for segmental defects of the femur, tibia, and humerus. Clin Orthopaedics Related Res. 2016;474:539-48.

14. Casadei R, Drago G, Di Pressa F, Donati D. Humeral metastasis of renal cancer: Surgical options and review of literature. Orthop Traumatol Surg Res. 2018;104(4):533-8. https://doi.org/10.1016/j.otsr.2018.03.009.

15. Dijkstra S, Stapert J, Boxma H, Wiggers T. Treatment of pathological fractures of the humeral shaft due to bone metastases: a comparison of intramedullary locking nail and plate osteosynthesis with adjunctive bone cement. Eur J Surg Oncol. 1996;22(6):621-6. https://doi.org/10.1016/S07487983(96)92450-6.

16. Carroll EA, Schweppe M, Langfitt M, Miller AN, Halvorson JJ. Management of humeral shaft fractures. J Am Acad Orthop Surg. 2012;20(7):423-33. https:// doi.org/10.5435/JAAOS-20-07-423.

17. Fuchs B, Ossendorf C, Leerapun T, Sim FH. Intercalary segmental reconstruction after bone tumor resection. Eur J Surg Oncol. 2008;34(12): 1271-6. https://doi.org/10.1016/j.ejso.2007.11.010.

18. Panagopoulos GN, Mavrogenis AF, Mauffrey C, Lesenský J, Angelini A, Megaloikonomos PD, et al. Intercalary reconstructions after bone tumor resections: a review of treatments. Eur J Orthop Surg Traumatol. 2017;27(6): 737-46. https://doi.org/10.1007/s00590-017-1985-x.

19. Zhao J, Yu XC, Xu M, Zheng K, Hu YC, Wang F, et al. Intercalary prosthetic reconstruction for pathologic diaphyseal humeral fractures due to metastatic tumors: outcomes and improvements. J Shoulder Elbow Surg. 2018;27(11):2013-20. https://doi.org/10.1016/j.jse.2018.03.027.

20. Zheng $K$, Yu XC, Hu YC, Shao ZW, Xu M, Wang BC, et al. Outcome of segmental prosthesis reconstruction for diaphyseal bone tumors: a multicenter retrospective study. BMC Cancer. 2019;19(1):638. https://doi.org/10.11 86/s12885-019-5865-0.

21. Chin HC, Frassica FJ, Hein TJ, Shives TC, Pritchard DJ, Sim FH, et al. Metastatic diaphyseal fractures of the shaft of the humerus. The structural strength evaluation of a new method of treatment with a segmental defect prosthesis. Clin Orthop Relat Res. 1989;248:231-9.

22. Henry JC, Damron TA, Weiner MM, Higgins ME, Werner FW, Sim FH. Biomechanical analysis of humeral diaphyseal segmental defect fixation. Clin OrthopRelat Res. 2002;396:231-9. https://doi.org/10.1097/00003086-2 00203000-00034.

23. Richards RR, An KN, Bigliani LU, Friedman RJ, Gartsman GM, Gristina AG, et al. A standardized method for the assessment of shoulder function. J Shoulder Elbow Surg. 1994;3(6):347-52. https://doi.org/10.1016/S1058-274 6(09)80019-0.

24. Gerrand $\mathrm{CH}$, Rankin K. A system for the functional evaluation of reconstructive procedures after surgical treatment of tumors of the musculoskeletal system. Clin Orthop Relat Res. 1993:286:241-6.

25. Damron TA, Leerapun T, Hugate RR, Shives TC, Sim FH. Does the secondgeneration intercalary humeral spacer improve on the first? Clin Orthop Relat Res. 2008;466(6):1309-17. https://doi.org/10.1007/s11999-008-0246-Z.

26. Blum J, Engelmann R, Küchle R, Hansen M, Rommens PM. Intramedullary nailing of humeral head and humeral shaft fractures. Eur J Trauma Emerg Surg. 2007;33(2):149-58. https://doi.org/10.1007/s00068-007-7035-3.

27. Enneking WF, Spanier SS, Goodman MA. A system for the surgical staging of musculoskeletal sarcoma. Clin Orthop Relat Res. 1980;153:106-20.

28. Sarahrudi K, Wolf H, Funovics P, Pajenda G, Hausmann JT, Vécsei V. Surgical treatment of pathological fractures of the shaft of the humerus. J Trauma. 2009:66(3):789-94. https://doi.org/10.1097/TA.0b013e3181692132.

29. Thai DM, Kitagawa Y, Choong PF. Outcome of surgical management of bony metastases to the humerus and shoulder girdle: a retrospective analysis of 93 patients. Int Semin Surg Oncol. 2006;3(1):5. https://doi.org/1 0.1186/1477-7800-3-5

30. Bickels J, Kollender Y, Wittig JC, Meller I, Malawer MM. Function after resection of humeral metastases: analysis of 59 consecutive patients. Clin Orthop Relat Res. 2005:437:201-8.

31. Capanna R, Campanacci DA. The treatment of metastases in the appendicular skeleton. J Bone Joint Surg Br. 2001;83(4):471-81. https://doi. org/10.1302/0301-620X.83B4.0830471

32. Franck WM, Olivieri $M$, Jannasch $\mathrm{O}$, Hennig FF. An expandable nailing system for the management of pathological humerus fractures. Arch Orthop Trauma Surg. 2002;122(7):400-5. https://doi.org/10.1007/s00402002-0428-1.

33. Tome J, Carsi B, Garcia-Fernandez C, Marco F, Lopez-Duran Stern L. Treatment of pathologic fractures of the humerus with Seidel nailing. Clin Orthop Relat Res. 1998;350:51-5.

34. Wedin R, Hansen BH, Laitinen M, Trovik C, Zaikova O, Bergh P, et al. Complications and survival after surgical treatment of 214 metastatic lesions of the humerus. J Shoulder Elbow Surg. 2012;21(8):1049-55. https://doi. org/10.1016/j.jse.2011.06.019.

35. Laitinen M, Nieminen J, Pakarinen TK. Treatment of pathological humerus shaft fractures with intramedullary nails with or without cement fixation. Arch Orthop Trauma Surg. 2011;131(4):503-8. https://doi.org/10.1007/s004 02-010-1172-6.

36. Ruggieri P, Mavrogenis AF, Bianchi G, Sakellariou VI, Mercuri M, Papagelopoulos PJ. Outcome of the intramedullary diaphyseal segmental defect fixation system for bone tumors. J Surg Oncol. 2011;104(1):83-90. https://doi.org/10.1002/jso.21893.

\section{Publisher's Note}

Springer Nature remains neutral with regard to jurisdictional claims in published maps and institutional affiliations.

Ready to submit your research? Choose BMC and benefit from:

- fast, convenient online submission

- thorough peer review by experienced researchers in your field

- rapid publication on acceptance

- support for research data, including large and complex data types

- gold Open Access which fosters wider collaboration and increased citations

- maximum visibility for your research: over $100 \mathrm{M}$ website views per year

At $\mathrm{BMC}$, research is always in progress.

Learn more biomedcentral.com/submissions 